\title{
Ensuring the Protection of Whistleblowers in Public Administration: The Experience of Georgia
}

\author{
Shalva (Lasha) Gogidze \\ Department of Public Administration and E-Business, Georgian Technical University \\ PO Box 0160, Kostava Street 77, Tbilisi, Georgia \\ E-mail: lashaberi@gmail.com
}

Received: Oct. 10, 2020 Accepted: Nov. 9, 2020 Online published: Nov. 19, 2020

doi:10.5296/jpag.v10i4.17772ＵRL: https://doi.org/10.5296/jpag.v10i4.17772

\begin{abstract}
This article reviews the role of the institute of whistleblowers in modern system of public administration and its connections to fighting corruption and detecting violations of legislative and ethical norms in public and private sectors. In this context, the article discusses the experience of Georgia, post-Soviet country that is in democratic transition with nascent norms and mechanisms for whistleblower protection. Specifically, the article analyzes Georgia's legislative norms and their practical application by bringing specific examples from within the country and abroad. This is complemented by the analysis of international norms and mechanisms the adoption of which would improve the status quo in the field and encourage more people in the Georgian state and civil service and beyond to raise their voices against injustices and unlawful and corrupt behavior. The article ends with the conclusion and a list of recommendations tailored to the Georgian context.
\end{abstract}

Keywords: whistleblower, whistleblower protection, public administration, civil service, private sector, corruption, violations, ethics, independent oversight, uniform statistics, proactive disclosure, compensation, awareness raising

\section{Introduction}

The institute of whistleblowers plays an important role in detecting violations of legislative and ethical norms and fighting corruption, both in the public and private sectors. This institute allows for the detection of violations that would otherwise be very difficult to detect and that would jeopardize public health and safety, the sound spending of public finances, human rights, the environment, and the rule of law. However, to reveal a specific breach, whistleblowers often take quite a big risk, which can even cost them their lives. It is therefore important to introduce strong mechanisms for the protection of whistleblowers in the 
legislation, and to enforce them effectively, so as not to endanger the whistleblowers' professional or personal lives due to the fact of disclosure (Gzirishvili, 2014). This is especially important when a state or civil service whistleblower exposes a higher-ranking civil servant or influential state official who may intimidate and harass the whistleblower through dismissal, pay cuts, defamation, harassment, or other means of retaliation. To prevent all this and to take a risky step to expose violations of the law and ethics, the whistleblower needs effective protection from the state. Solid whistleblower protection mechanisms in turn increase both public and private sector transparency, integrity, and accountability to the citizens.

The most famous whistleblower, Edward Snowden, made a special contribution to raising public awareness about the institute of whistleblowers. Snowden is an American computer security specialist who held senior positions in the US National Security Agency and its contractors from 2006-2013. With the help of the Guardian newspaper, he published secret materials in June 2013, which confirmed the facts of illegal surveillance of the telephone and internet communications of US and foreign citizens and political leaders by the US authorities (Greenwald, 2014). By doing so, in particular by misappropriating state property and by disclosing secret information, Snowden violated the U.S. Espionage Act 1917 and federal criminal law, for which he faces up to at least 30 years in prison. It is noteworthy that in order to avoid straining relations with the US, many countries refused to grant asylum to Snowden, who left the US before the release of the secret materials. The only country that agreed to this was the Russian Federation, and Snowden has been living in Moscow since 2013. For exposing information containing state secrets, many denounced Snowden as a traitor and demanded a longer prison term for him, but he also became a patriot and hero for many for his courage in publicizing human rights abuses by the US government (Lepore, 2019).

Snowden himself believes that he is neither a traitor nor a hero, but an ordinary American who wanted to change the injustices he witnessed. He believes that if not him, someone else would have done it instead of him, and he brought the famous words of Benjamin Franklin as evidence: "Those who would give up essential Liberty, to purchase a little temporary Safety, deserve neither Liberty nor Safety" (Simpson, 2013).

Snowden's disclosure has really brought about change both in the US and abroad. In particular, in 2015, the US passed the Freedom Act, which significantly restricted the collection of telephone records of US citizens (Siddiqui, 2015). The U.S. Congress also shut down a program that systematically collected and analyzed Americans' home phone calls and text messages (Savage, 2019). Other countries have adopted new legislation on the protection of personal data and whistleblowers, and have helped to raise public awareness of these issues.

\section{Legal Protection of Whistleblowers in the Country of Georgia}

Whistleblowing has a negative connotation in post-Soviet countries, which is mainly due to cultural factors stemming from the Soviet legacy, according to which reporting on someone, despite the violation committed, brings the memories of KGB arrests and repressions and is 
therefore considered unacceptable behavior for many. Georgia is one of such countries that is still in democratic transition with nascent norms and mechanisms for whistleblower protection. Georgia first adopted the norms on the protection of whistleblowers in 2009 in the Law on Conflict of Interest and Corruption in Public Service. However, these norms were so scarce, general and declarative in nature that they did not offer whistleblowers specific safeguards (Law of Georgia on Conflict of Interest and Corruption in Public Service, 2009). Significant amendments to this law were made shortly after the publication of Snowden's materials, in particular in 2014-2015. The new norms now protect not only the whistleblowers, but also their close relatives. The definition of whistleblowing has been expanded to include, in addition to violations of the law and general rules of conduct, disclosures of breaches of ethics. It has been determined that this breach covers not only the damage already caused to the public interest or the reputation of the relevant public institution, but also possible damage. A presumption of good faith has been added to the definition of whistleblowing, according to which disclosure is considered bona fide until proven otherwise. It was also determined that the disclosure may be anonymous if the whistleblower does not express the will in writing to reveal his or her identity. The body reviewing the whistleblower statement is obliged not to disclose the identity of the whistleblower, and violation of this obligation by a civil servant will result in disciplinary action. The circle of bodies where it is possible to send a statement of disclosure has expanded. The structural subdivision of the relevant public institution carrying out the internal control and / or service inspection, Investigator, Prosecutor and Public Defender were defined as internal disclosure bodies. Following a decision by these bodies, the whistleblower can also appeal to external disclosure bodies, in particular the media and civil society. A variety of forms of disclosure were identified: in writing, orally, electronically, by telephone, by fax, through a special website administered by the Civil Service Bureau, www.mkhileba.gov.ge, or by other means. Finally, in order to ensure the impartiality of the decision-making process regarding the fact of disclosure, it became inadmissible for the person exposed or a person directly or indirectly interested in the outcome of the decision to consider the disclosure statement (Law of Georgia on Conflict of Interest and Corruption in Public Service, 2015).

Despite the positive changes mentioned above, the legal guarantees for the protection of whistleblowers in Georgia are still scarce, which is confirmed by the fact that the existing norms are practically dysfunctional and are not used either in the civil service or outside it. Referring to the law and systemic shortcomings, local Civil Society Organizations (CSOs) explain the problems related to the enforcement of whistleblower legislation. In their view, the scope of whistleblowing in existing legislation is still limited, as it does not contain a clear list of actions, including those involving issues of state security and state secrets, that may be exposed by whistleblowers and do not oblige public institutions to establish clear internal rules and procedures for whistleblowing. For example, the Ministry of Defense, the Ministry of Internal Affairs, and the State Security Service have not yet adopted special legislation to regulate whistleblowing in their systems (Transparency International Georgia, 2015), despite the fact that the Law of Georgia on Conflict of Interest and Corruption in Public Service directly mentions this obligation. There is also no common standard or 
approach to identifying whistleblower statements in the civil service that would make it easier for public institutions to distinguish whistleblower statements from other types of disclosure statements and complaints. Most importantly, there is no responsible oversight body that: collects and publishes unified statistics on cases of whistleblowing and responses to them and data on public awareness of the institute of whistleblowers; develop minimum standards for whistleblowing; monitor the implementation of such standards in public institutions; advise stakeholders on issues related to whistleblowing; oversee the investigation of whistleblowers' allegations; and investigate cases of pressure on whistleblowers (Transparency International Georgia, 2020).

\section{The Georgian Practice of Whistleblowing}

Legal shortcomings also cause practical difficulties. For example, the aforementioned official website for whistleblowing, www.mkhileba.gov.ge, has quite a few users and this number is decreasing every year. According to the latest data published by Transparency International Georgia, in 2017, 111 whistleblower statements were sent to the Civil Service Bureau using this website, and in 2019 this number was reduced to 24. In addition, there is no formal advisory service on issues related to whistleblowing, such as a hotline that would help whistleblowers report information about a specific breach quickly and receive appropriate advice from the state (Transparency International Georgia, 2020).

Given these legal and practical difficulties, whistleblowers prefer to bypass the law and the state system and to directly inform the media, civil society organizations or the general public about corruption or other types of legislative and ethical violations in the civil service. A clear manifestation of this were two facts that occurred in October 2019.

In the first case, an employee of the Tbilisi City Council (Sakrebulo) exposed a member of the same Sakrebulo for sexual and physical violence, which she reported to the Ministry of Internal Affairs. However, after law enforcement officers did not immediately follow up with the victim to inspect the scene of the incident and only arrived at the scene later, the victim suspected that law enforcement officers were not investigating the case properly because the person exposed was a political official. Accordingly, the Sakrebulo employee, bypassing the Sakrebulo, the Investigator, the Prosecutor and the Public Defender, addressed the mass media directly, and asked the civil society organization to protect her rights (Civil.ge, 2019). Following the publication of the case and its details, the Prosecutor's Office charged the exposed Sakrebulo member and demanded a bail of GEL 10,000 (Netgazeti, 2019). As of October 2020, the court hearings on the case were not yet completed. In the second case, the former Prosecutor, after leaving Georgia, wrote publicly on her Facebook page about the reasons why she decided to leave the Prosecutor's Office. Among the reasons cited were violations of the law and ethics in the system and corruption, such as nepotism, selective justice, sexual harassment by a supervisor, verbal abuse and humiliation, unlawful assignment and unequal distribution of labor. Following the publication of this statement, the General Inspectorate of the Prosecutor's Office launched an official investigation to study the circumstances of the statement in detail and to take appropriate legal action (Radio Liberty, 2019). However, as of October 2020, the results of this inspection were unknown. 
Along with Snowden's example, both of Georgia's examples clearly show that civil servants do not feel safe if they expose their supervisors in violation of the law within the state system itself. Due to the lack of trust in state structures, they prefer to make public the facts of the violation by bypassing the internal system, through the external channels, such as mass media, civil society organizations or social media platforms, and thus gain the support of the general public. The whistleblowers believe that as a result of their public disclosures and public pressure, the chances of a proper legal response to the facts of the violation increase and that the state is more likely to make systemic changes to prevent breaches of the law and ethics and to prevent corruption. As mentioned above, following Snowden's public disclosures, the US government has indeed made systemic changes to curb illegal telephone tapping of its own citizens, and in Georgia, in the first case, the public disclosure resulted in a member of the City Council being charged, and in the second case, the Prosecutor's Office launching an investigation.

However, in the context of public administration, it is important to analyze the legislative norms and practical mechanisms that would give whistleblowers more guarantees of protection within the state system and make them more courageous in applying these norms and mechanisms.

\section{International Norms and Recommendations for the Protection of Whistleblowers}

Georgia has ratified key international anti-corruption conventions, such as the UN Convention Against Corruption and the Council of Europe Civil and Criminal Law Conventions on Corruption. The UN Convention states that each State Party must ensure that appropriate measures and systems are in place in its domestic law "to provide protection against any unjustified treatment for any person who reports in good faith and on reasonable grounds to the competent authorities any facts concerning offences established in accordance with this Convention." This includes providing the opportunity for anonymous disclosure of corruption violations (UN Convention Against Corruption, 2004). The same norms are contained in the Council of Europe Civil and Criminal Law Conventions on Corruption.

Based on these norms, Transparency International has developed 30 guidelines for ensuring the legal protection of whistleblowers. Given that most of these norms are already enshrined in Georgian legislation, this article focuses on norms that have not yet been considered and which will play an important role in the development of the whistleblower institute in the country.

First of all, it is recommended to adopt a standalone law on the protection of whistleblowers. This will facilitate the clear formulation and consolidation of all important regulatory norms in this area and the setting up of their enforcement mechanism into a single normative act, effective and consistent implementation of these norms, and raising the awareness of the general public. Many countries, including the United States, the United Kingdom, Ireland, the Netherlands, Malta, Serbia, New Zealand, Australia and South Korea, have adopted such standalone laws (Transparency International, 2018).

Second, the definition of whistleblowing itself must be specific and at the same time it must 
cover a wide scope. According to Transparency International, whistleblowing is defined as "the disclosure of information related to corrupt, illegal, fraudulent or hazardous activities being committed in or by public or private sector organisations - which are of concern to or threaten the public interest - to individuals or entities believed to be able to effect action" (Transparency International, 2013). This definition makes it clear that the whistleblower's disclosure includes not only violations committed by a civil servant, but also violations committed by persons employed in the private sector, including interns and persons hired on a contract basis. Most importantly, information on these violations can be provided to both public and private sector individuals or legal entities without any restrictions, such as appealing to external disclosure bodies only after a decision has been made by the review body within the state system. Third, intimidation, harassment, coercion, humiliation, persecution, pressure, moral or material harm, use of violence or threats of violence, discriminatory treatment or other unlawful acts inflicted on whistleblowers or on their close relatives should be punished, and the sanctions should be specified in the relevant law. Depending on the gravity of the act committed, the sanctions may include imposing an administrative penalty on the person exposed or a related person with a specific amount, civil liability with a specific measure, or criminal liability with a specific sentence (Transparency International, 2018).

Fourth, whistleblowers should be given adequate compensation for the damage caused by the fact of disclosure. In particular, a whistleblower who is a victim of harassment has the right to claim compensation that covers the direct, indirect and future consequences of any repressive action. Compensation should include a court injunction as a means of ensuring that the whistleblower maintains the status quo held prior to the fact of disclosure; attorney service and mediation fees; transfer to another department or subordinate to another supervisor if necessary; compensation for loss of past, present or future income or status; compensation for pain and suffering, medical expenses for treatment of the effects of physical and psychological violence, provision of temporary accommodation, and protection of personal data (Transparency International Georgia, 2015).

Moreover, in the event of a breach disclosure that has prevented serious harm to the public safety and interests, whistleblowers may receive special rewards, benefits, promotions, funding for education and training, or other incentives from the state if they consent (Transparency International, 2018).

Another important recommendation is the establishment of an independent body to investigate whistleblowers' complaints. This body should be empowered to investigate both the facts of disclosure made by the whistleblowers as well as the harassment of whistleblowers, and to issue mandatory instructions to relevant persons. The mandate of such an agency may also include monitoring the enforcement of whistleblower legislation and implementing public awareness measures on the issue. The CSOs in Georgia have long called for the establishment of an independent anti-corruption agency, which would have the authority to investigate the so-called "elite corruption" cases involving high-ranking state-political officials and civil servants. They point out that the Anti-Corruption Council set up under the Ministry of Justice, which is made up of the state and a small number of civil 
society representatives, does not have such a mandate, and the State Security Service is less enthusiastic about investigating corruption cases involving ruling party members or high-ranking state officials. The CSOs believe that the establishment of an independent anti-corruption agency in Georgia will provide an important springboard for the fight against corruption at all levels of government (OGP Independent Reporting Mechanism, 2019).

To ensure the protection of personal data and the open data standards, the above-mentioned independent agency should publish reports on the application of whistleblower legislation at least once a year. These reports should include the following types of information: the number of whistleblower statements, the timing of the review of these statements and the status of their resolution; amount and description of compensation paid to whistleblowers, dynamics of violations of law and ethics in the public and private sectors, and degree of public awareness and trust in whistleblower protection mechanisms (Transparency International, 2018).

Finally, it is important to raise public and private sector awareness as well as the awareness of the general public about the whistleblower institute, whistleblower protection legislation and practical mechanisms. Special information campaigns and trainings should focus on the following issues: the rights and responsibilities of whistleblowers and persons exposed and sanctions for violation of these rights and responsibilities; disclosure notification communication channels and procedures for application to review bodies. Awareness-raising activities also include the placement of information by employers in conspicuous places about whistleblower protection legislation and the organization's internal rules and procedures on integrity; as well as special training of the staff of the internal control and / or service inspection units for proper response to whistleblower cases (Transparency International Georgia, 2015).

\section{Conclusion and Recommendations}

Whistleblowers play a key role in exposing corruption, lawlessness, bad governance, or other acts that can seriously damage public safety, the environment, and human rights, as well as the rule of law. They often do this even at the cost of their own careers and lives, especially when exposing influential people in power. It is therefore important for the state to establish legal or practical safeguards for whistleblowers that will protect them from retaliation on the one hand, and encourage them, their colleagues or other members of society to expose the violations and perpetrators in the future. It also envisages the implementation of large-scale measures to raise public awareness on this issue, which will help to overcome the existing stigma regarding the disclosure of facts of violations in the office. The introduction of robust and clear legal norms for the protection of whistleblowers and effective mechanisms for their enforcement in practice is a requirement of the anti-corruption conventions of the UN and the Council of Europe and a necessary precondition for transparency, integrity, and accountability of the public and private sectors.

The country of Georgia strives to break away from the Soviet legacy of totalitarianism and intimidation through closer integration with Euro-Atlantic structures and through adherence to good governance and integrity standards in public administration that are recognized in 
those structures. This includes developing robust legal norms and state mechanisms for whistleblower protection, something that is still a work in progress. With the legislative changes of 2014-2015, Georgia has significantly improved the existing norms governing whistleblower protection in following areas: expanding the definition of whistleblowing; increasing the number of whistleblower statement review bodies; adding various channels of communication for disclosure; envisaging disclosure of good faith; expanding the law to close relatives of whistleblowers; and protecting the impartiality of the decision-making process and the anonymity of whistleblowers.

However, these positive changes have not been sufficient to ensure the application of the aforementioned legislative norms in practice, despite the fact that there are both the perpetrators of violations of the law and ethics in the country's civil service as well as their whistleblowers. The latter prefer to bypass the legislation and to expose the relevant offenders directly to the media and civil society, indicating whistleblowers' lack of trust in the state system. In response to this challenge, it is important for Georgia to make additional changes to existing legislation in line with internationally recognized standards and recommendations. This primarily implies a clearer definition of the norms governing the protection of whistleblowers and the mechanisms for their enforcement, which may serve as a basis for the adoption of a standalone law. This also implies establishment of an independent oversight body to be responsible for producing and publishing uniform statistics on whistleblower statements and state measures in response to those statements; investigating whistleblowers' complaints and cases of their harassment, and monitoring law enforcement. The Ministries of Defense and Interior and the State Security Service should promptly adopt special legislation on whistleblowing within their systems to better regulate the whistleblowing procedures on matters of state security and state secrets. The Government should ensure the provision of adequate compensation for whistleblowers being victims of harassment. It should regularly update the official whistleblowing website, www.mkhileba.gov.ge; proactively publish the statistics on the whistleblower statements on this website, and promote it to the general public. Finally, the Government should conduct large-scale information campaigns to raise public awareness about the whistleblower institute.

With these changes, Georgia will take another major step forward in the fight against corruption, increasing transparency, integrity, and accountability of the public and private sectors, and in promoting citizen participation in decision-making, which is a prerequisite for good governance and democracy. This in turn will increase public confidence in the state system and accelerate Georgia's integration into Euro-Atlantic structures.

\section{References}

Civil.ge. (2019, October 7). “Tbilisi Sakrebulo Member Accused of Sexual Violence”.

Council of Europe (1999). Civil Law Convention on Corruption. Retrieved from https://bit.ly/3a6pZ0O 


\section{Ml Macrothink}

Journal of Public Administration and Governance ISSN 2161-7104 2020, Vol. 10, No. 4

Council of Europe (1999). Criminal Law Convention on Corruption. Retrieved from https://bit.ly/2JY455k

Greenwald, G. (2014). "No Place to Hide: Edward Snowden, the NSA and the Surveillance State", Penguin Books.

Gzirishvili, T. (2014, June 18). "Georgia Improves Whistleblower Provisions But More Changes Needed”. Retrieved from https://bit.ly/32uKkv9

Law of Georgia on Conflict of Interest and Corruption in Public Service (2009, April 4). Retrieved from https://bit.ly/34mlIXJ

Law of Georgia on Conflict of Interest and Corruption in Public Service (2015, October 27). Retrieved from https://bit.ly/34uZK4O

Lepore, J. (2019, September 16). "Edward Snowden and the Rise of Whistle-Blower Culture", The New Yorker. Retrieved from https://bit.ly/2Rh3M9O

Netgazeti. (2019, December 25). "Ilia Jishkariani's Trial is Openly Considered by the Court". Retrieved from https://bit.ly/3bcXmk5

OGP Independent Reporting Mechanism (IRM) (2019, August 3). "Georgia End-of-Term Report (2016-2018)”, pg.33. Retrieved from https://bit.ly/2YqDJR4

Radio Liberty (2019, October 23). "27 "Because" of Which the Prosecutor Resigned. Retrieved from https://bit.ly/34ucve6

Savage, Charlie (2019, March 4). "Disputed N.S.A. Phone Program Is Shut Down, Aide Says", The New York Times. Retrieved from https://nyti.ms/2wpJVOw

Siddiqui, Sabrina (2015, June 3). "Congress Passes NSA Surveillance Reform in Vindication for Snowden", The Guardian. Retrieved from https://bit.ly/2JQMRXf

Simpson, Connor (2013, June 12). "Snowden Speaks: 'I'm Neither Traitor Nor Hero. I'm an American. The Atlantic. https://bit.ly/2JIiLFu

Transparency International Georgia (2020, June 25). "The Dysfunctional Whistleblowing Mechanism in the Georgian Public Service. Retrieved from https://bit.ly/2QfFw6X

Transparency International Georgia (2015, July 29). "Whistleblower Protection International Practices and Recommendations for Georgia. Retrieved from https://bit.ly/3aU8KSn

Transparency International (2018). “A Best Practice Guide for Whistleblowing Legislation. Retrieved from https://bit.ly/2YGjMGb

Transparency International (2013). "International Principles for Whistleblower Legislation: Best Practices for Laws to Protect Whistleblowers and Support Whistleblowing in the Public Interest. Retrieved from https://bit.ly/2EfGs92

UN Convention Against Corruption (2004). Retrieved from https://bit.ly/2V6q2pd 


\section{Macrothink}

Journal of Public Administration and Governance ISSN 2161-7104 2020, Vol. 10, No. 4

USA Freedom Act (2015, June 2). Retrieved from https://bit.ly/2Kd0AYK

\section{Copyright Disclaimer}

Copyright for this article is retained by the author(s), with first publication rights granted to the journal.

This is an open-access article distributed under the terms and conditions of the Creative Commons Attribution license (http://creativecommons.org/licenses/by/4.0/). 